\title{
A Methodological Approach for Assessing the Safety of Historic Buildings' Façades
}

\author{
Giovanni Ruggiero $^{1}$, Rossella Marmo ${ }^{2, *}$ and Maurizio Nicolella ${ }^{1}$ \\ 1 Department of Civil, Architectural and Environmental Engineering, University of Naples Federico II, \\ 80125 Naples, Italy; giovanni.ruggiero2@unina.it (G.R.); nicolell@unina.it (M.N.) \\ 2 Department of Civil Engineering, University of Salerno, 84084 Fisciano, Italy \\ * Correspondence: rmarmo@unisa.it
}

Citation: Ruggiero, G.; Marmo, R.; Nicolella, M. A Methodological Approach for Assessing the Safety of Historic Buildings' Façades. Sustainability 2021, 13, 2812. https:// doi.org/10.3390/su13052812

Academic Editor: Giovanna Acampa

Received: 2 February 2021

Accepted: 1 March 2021

Published: 5 March 2021

Publisher's Note: MDPI stays neutral with regard to jurisdictional claims in published maps and institutional affiliations.

Copyright: (c) 2021 by the authors. Licensee MDPI, Basel, Switzerland. This article is an open access article distributed under the terms and conditions of the Creative Commons Attribution (CC BY) license (https:// creativecommons.org/licenses/by/ $4.0 /)$.

\begin{abstract}
Inefficiency in maintaining and managing architectural heritage threatens both heritage conservation and public safety. Damage related to collapsed building elements requires an investigation into the factors which cause these phenomena in order to prevent them and to mitigate their effects. This paper aims to define a methodological approach for assessing the risk to humans of falling bodies from historic buildings' façades. The method is based on the identification of a group of parameters to assess façade's hazards, vulnerability and public exposure. The results provide the identification of risk factors and related affecting parameters, proposing a synthetic indicator to quantify the risk. The proposal is original in the field of both maintenance planning and preventive maintenance, intending to preserve architectural heritage and public safety. The results lead to an easy tool, as a map, to prioritise risk mitigation interventions. Such a tool, if integrated into maintenance tenders, allows the evaluation, in the context of condition-based maintenance, of the need for interventions.
\end{abstract}

Keywords: maintenance management; condition assessment; degradation; public safety; risk assessment

\section{Introduction}

During the last ten years, more than forty hazardous events due to falling bodies from historic buildings' façades have been reported by the authors in Naples, Italy. The relevance of such a phenomenon led the authors to investigate the risk for humans ascribed to it and to deepen the factors which cause it.

According to the International Organisation for Standardization (ISO), the risk could be defined as a combination of the probability of an event and its consequences, or, similarly, according to the National Institute for Occupational Safety and Prevention (ISPESL), risk can be defined as a function of the event probability and the damage magnitude.

Risk assessment strategies are also applied to historic buildings conservation. The Italian Legislative Decree n.42/2004 declares that cultural heritage can be protected and preserved by means of preventive, maintenance, and restoration actions. The implementation of preventive measures requires a thorough knowledge of the risks historic buildings are facing. Before planning and programming maintenance strategies, inspections and monitoring activities are needed to evaluate the building conservation condition and the risks in place [1]. In this context, Cecchi and Gasparoli [1] defined risk as the result of the combination of environmental hazards, vulnerability, and exposure of the building. Risk is the measure of the level of damage which can occur within a certain time period according to the site hazards (climate, seismic, anthropogenic, hydrogeologic) and to elements' vulnerability (decay, resistance to seismic actions, quality and quantity).

Hazard, vulnerability and exposure are the main components of the risk for the safety of archaeological architectures according to the guidelines for the conservation of architectures of archaeological interest [2]. Hazard is defined as the likelihood of an occurrence of a natural event in a given period of time, and vulnerability is the willingness 
of each element to be damaged by an external cause related to physical and anthropic environments. Vulnerability is an intrinsic characteristic of an element and it depends on the element's conservation state. Exposure is defined as the quantity and the quality of goods (in this case, archaeological heritage) exposed to an environmental phenomenon. In order to determine if a risk condition is in place, it is necessary to combine vulnerability, exposure and hazard and to evaluate the evolution of degradation phenomena; the loss of elements' functionality; the damages to contiguous elements; and the damages to people.

Other approaches have been proposed in order to apply vulnerability and service life indexes to the preventive conservation of cultural heritage [3]. Preventive conservation studies the risks of monuments aiming at understanding the threats and the current conservation condition to minimize further degradation and increase the service life of buildings [4]. Vulnerability is intended as the degree of health or disease of a monument, while functionality (or service life) depends on intrinsic variables (e.g., constructive system) and extrinsic variables (e.g., geological situation). These indexes aim to provide scientific criteria to develop policies for decision making regarding urgent monument restoration tasks [3,4]. Estimating building elements' service life and durability has a great impact on preventive maintenance. For this purpose, an international database has been proposed to ascribe to each kind of technical element or material its reference service life as a starting point to obtain the value of the estimated service life [5]. Other relevant guides are those proposed by Perret [6] and Socotec [7], which starting from practical experiences, offer forms to gather building information and lead the user to a list of possible maintenance interventions. Other databases have been implemented to catalogue element failures and mechanisms of breakdown [8].

Correlations between service life, the durability of building components and maintenance strategies are exposed below.

\subsection{Building Degradation and Maintenance Planning}

Over the last 40 years, maintenance in the building sector has had an extraordinary evolution, which has led, from the intuition of the possibility to import models and methodologies from the industrial sector, to the current implementation of a great digitalisation, passing through the materialization of typologies of contracts increasingly marked by an evolution of management models.

Today, therefore, it is somewhat surprising if this ability to adapt to the logic of the job sector has left behind some unsolved issues, which seem to be immune to the aforementioned evolutions and which continue to remain in the shadows at the bottom of the criticalities in maintenance. The most important topics in the maintenance sector over the last few decades have regarded strategies, management models, diagnostics, contracts, life cycle evaluation, management tools, life cycle cost, information systems, monitoring, key performance indicators, and digitization. It can be said that the world of research has made, at an international level, a common front towards many of them, proposing techniques and methodologies of great interest and usefulness.

In reality, there is a question which is indeed characterized by considerable complexity, and which, despite having been the subject of many scientific works and many proposals, remains, in truth, controversial and difficult to solve. This refers to the evaluation of the performance of building components and their non-bistability, which has always been a relevant problem for maintenance planning due to the challenges in assessing whether the component is to be considered in an operating or non-operating state. For this reason, many researchers investigated coding systems, methodologies to perform parametric estimations, rating systems for attempting to transform the "discrete" into "continuous". "Buildings are complex systems composed of several different assemblies/materials, which increase the uncertainty level of planning and performing building maintenance", has been appropriately observed [9]. The approaches followed by researchers around the world on this topic have been quite varied and mixed with the topics listed above. 
Regarding the methodologies for choosing the maintenance strategy, many approaches have been attempted, including Markovian chains or fuzzy logic, but also neural or Bayesian networks, in the evident intention to give to a problem, characterized by a certain irrationality, a systematization which tends to sympathize with Artificial Intelligence techniques, drawing all the ideas above from Expert Systems, which were common in the 1990s. In this regard, contributions that have concerned, with a Markovian approach, the civil sector in general, include infrastructural works [10], with an approach specifically dedicated to the economic problem, optimized by means of stochastic models. In particular, the importance of optimizing maintenance strategies is emphasized by LCC (Life Cycle Costing) approaches, where the total costs of design, building, maintenance, and demolition are considered over the entire life span of the system, taking into account uncertainties depending on failures and/or deteriorating conditions. Mazzucchi et al. [11] reviewed mathematical decision models to optimize time-based maintenance (e.g., in terms of age- and block-replacement intervals) and condition-based maintenance (e.g., in terms of inspection intervals): "Using renewal theory, optimal maintenance decisions under uncertain deterioration can be determined for which the expected nondiscounted cost per unit time or the expected discounted cost over an unbounded time horizon is minimal. Using Bayesian statistics, these optimal maintenance decisions can be adapted on the basis of observations". Further developments are proposed in other works, which likewise use the Markovian approach for the rationalization of maintenance activities, but also to attempt the evaluation of components' conservation conditions. "The models are intended to increase insight into strategic maintenance decision making and are in a preliminary phase only. Each building is divided into several parts, which state is determined each year by inspection and the result classified on a 6-point scale (varying from excellent condition to a very bad condition). Assuming residence times for each state, a semi-Markov decision model (SMDM) can be formulated with several maintenance actions in each state" [12]. This research is, moreover, among those which have taken into account the economic aspects in the planning of maintenance activities, while expenditure planning and budgeting remain some of the most important and complex problems: "From norms on the maximal discounted frequencies of certain states a minimum discounted cost policy can be determined by formulating the SMDM as a linear programming model. To incorporate the initial state of buildings and yearly budget constraints, however, the SMDM has to be transformed into an equivalent Markov decision model (MDM) with the residence time as second state variable. Modelling deterioration dependencies between, e.g., protective parts (painting) and protected parts, however, leads to very large states spaces. Furthermore, a discounted cost analysis does not allow the control over the long-term average state frequencies. Finally, by averaging over all building parts the MDM also allows the construction of a so-called tradeoff curve between the average condition of buildings and the long-term average costs required to keep the buildings in that condition" [12]. Other authors have tried to systematize a basically irrational problem with rationalistic-stochastic approaches, always with Markov chains but with the help of a Building Management System, for determining the best strategy in terms of maintenance planning [13]: "This software uses a genetic algorithm applied to Markov Chains to estimate the best maintenance plan. This simulation compares different maintenance plans actions. Each one considers different material properties in a building façade and consequently the building's performance varies during its service life. The varying durability is given by the transition probability of the Markov Chain method ( ... ). The best maintenance plan can be characterized as the plan offering the lowest global cost over a certain analysis period which allows an acceptable degradation level, as established by the building manager. The genetic algorithm was used to generate multiple combinations of adequately-performing maintenance actions in order to obtain the best result".

In recent years, and reasonably, there has been a great increase in studies on the digitization of maintenance plans and building management in general. Links were stablished between maintenance and Building Information Modelling, BPADs (Building 
Performance Attribute Data), AIM (Asset Information Model), Building Management System, with Computer Aided Facility Management Systems, and all the software created for facility management. A huge interest, in this regard, is lifted by a research that, at least, proposes a conceptual framework on the use of effective information management and the aggregation of BPAD with AIM [14].

Whole international conferences have been dedicated to the problem of determining the life cycle of building components, such as DBMC (Durability of Buildings, Materials, and Components). International legislation, as well, has been following the numerous and significant developments of research with the publications of important standards such as ISO 15686, which includes the Factor Method, now considered an international reference standard. An excerpt from one of the thousands of publications on the subject summarises the main point: "The sustainability of the built environment can only be achieved through the maintenance planning of built facilities during their life cycle, considering social, economic, functional, technical, and ecological aspects. Stakeholders should be conscious of the existing tools and knowledge for the optimization of maintenance and rehabilitation actions, considering the degradation mechanisms and the risk of failure over time. Knowledge concerning the service life prediction of building elements is crucial for the definition, in a rational and technically informed way, of a set of maintenance strategies over the building's life cycle. Service life prediction methodologies provide a better understanding of the degradation phenomena of the elements under analysis, allowing relating the characteristics of these elements and their exposure, use, and maintenance conditions with their performance over time" [15].

The truth is that in many contexts, both for the public and the private sector, the motivational impulse remains economic: for most Public Bodies, the amount of budget allocated for ordinary maintenance is gradually decreasing, making policies with a programmatic matrix basically impracticable, while private individuals have now assumed a widespread attitude of clinging to the possibility of using incentives or benefits from the state.

Additionally, some authors highlighted the danger related to some uncertainties: excessively long horizons for maintenance plans [16], and especially the impact of "imperfect maintenance actions", for which a new methodology has been proposed, based on a probabilistic approach, implemented through a stochastic maintenance model based on Petri Nets. The impact of the actions of imperfect maintenance on the overall degradation condition of the components of buildings' envelope is assessed through the expression of a numerical index called "severity of degradation" [17].

The economic issue actually has multiple facets, even if examined from the point of view of the relationship between maintenance personnel and top managers: "The maintenance objectives will be considered in connection with the organisational objectives. However, there are limited studies of how building maintenance objectives match with the organisational objectives in an organisation ( . . ) Planning of maintenance objectives have impacts on the facility management operation in terms of using different maintenance strategies, which are influenced by the cost, quality and process directly and indirectly (...) it is recommended to collect the data and information about how maintenance personnel develop building maintenance objectives ( . . . ). Understanding the relationships between the top management at the strategic level and maintenance personnel at the operational level are considered important for better management of building maintenance operation processes" [18].

In the specific context of performance evaluation, to which this article belongs, numerous studies have focused on the discretization of the reality into parameters. To do this, they have aimed at the creation of numerical indexes, similar to the KPIs (Key Performance Indicators), which in the maintenance sector have been mainly used for evaluations of more generic nature rather than for single components.

Studies on this topic have been well highlighted by an interesting and recent literature review [19], which compares different methodological proposals [20-29] and reaches very interesting conclusions which validate the thesis of a substantial difficulty in simpli- 
fying and objectifying the problem: "There is lack of mechanism to prioritize the most vulnerable building components in existing building component rating systems. Future research in development of new building component rating system should focus on reducing or eliminating subjectivity from assessment. Visual inspection which is one of the most widely accepted methods of building inspection must be complimented with use of Non-Destructive Testing instruments in evaluation to provide more reliable information and uniformity in assessment with less subjective results. A new, more objective, quick, economical and technology-based building component inspection system which is not affected by type or age of building is needed, to translate evaluation output into a reliable, consistent and easy to understand building rating system".

It can be said that, in a certain sense, these are among the main reasons behind this research.

\subsection{Research Contribution}

The deterioration of construction materials and the lack of systematic maintenance [1], as well as numerous environmental variables [4], are among the main factors which affect the conservation of architectural heritage and as a consequence public safety. Historic buildings management requires maintenance as a process; therefore, further investigation is needed to define indicators to quantify and to monitor building performances over time [1]. Hazards and vulnerability analysis are the first step for risk assessment and for preventive interventions [1,4].

In this context, this article aims at developing an approach to assess the risk to humans related to falling bodies from historic buildings' façades. The following key objectives have been established:

- Identifying parameters to describe and evaluate building elements hazard, people vulnerability and exposure;

- Defining a performance indicator, based on these parameters, for risk assessment;

- Testing the proposed approach on a case study to provide the proof of concept.

This paper is structured as follows: Section 1 sets out the main concepts for risk assessment and it outlines correlations between material degradation and maintenance strategies; the methodological approach for risk assessment is described in Section 2; the case study context is reported in Section 3; the approach has been implemented on a real building and results are exposed in Section 4; and this is discussed in Section 5. Section 6 outlines the strengths and limitations of the current work as well as future improvements.

\section{Materials and Methods}

Previous works provided strategies for the conservation of historic buildings [1-4] and building rating systems [19-29]. In particular, methods for building condition and risk assessment, as a first step for maintenance planning, have been retrieved from Cecchi and Gasparoli [1]. Material deterioration and element service life are key components for risk assessment. These components are affected by external conditions (e.g., environment, crowding) and intrinsic features (e.g., materials, construction details, position). Even though materials provided by the scientific literature guided the authors in identifying risk factors, the change of perspective proposed by this paper, which argues for people safety rather than material loss, led to a novel approach.

This section provides an analysis of the main parameters involved in the risk assessment associated with falling bodies from buildings' façades, and it proposes a performance indicator to quantify such a risk. The authors interpreted risk and related factors from a perspective based upon the damage to humans due to building façade degradation. Thus, they provided novel definitions of risk factors, expressing the risk as a combination of hazard, vulnerability and exposure as in Equation (1):

$$
\mathrm{R}=\mathrm{f}(\text { Hazard,Vulnerability,Exposure), }
$$


where:

- Hazard is the probability that an element of a building's façade, in a given time period, falls and causes injury to somebody or damage,

- Vulnerability is the tendency of people to be damaged due to falling bodies from buildings' façades,

- Exposure is related to the amount of people exposed to danger.

The proposed methodology relies on partitioning building façades into finite elements by means of a grid based on $0.7 \times 0.7 \mathrm{~m}$ cells. This size of the cells comes from a comparative analysis between façade's technological element surfaces and grid cell surfaces approximating those elements, which led to the size of $0.7 \times 0.7 \mathrm{~m}$ as the optimal choice in terms of façade's approximation and efforts required to analyse it. In this way, a risk value is associated with each cell, and the façade's overall risk is a combination of the former.

Usually a risk value is obtained by multiplying factors (i.e., hazard, vulnerability and exposure). The risk value ascribed to each façade's cell is obtained as in Equation (2):

$$
R(x, y)=P(x, y) \times V(x, y) \times E(x, y) \text { con } x, y \in N
$$

where:

- $\mathrm{R}(\mathrm{x}, \mathrm{y})=$ risk indicator,

- $\mathrm{P}(\mathrm{x}, \mathrm{y})=$ hazard factor,

- $\mathrm{V}(\mathrm{x}, \mathrm{y})=$ vulnerability factor,

- $\mathrm{E}(\mathrm{x}, \mathrm{y})=$ exposure factor,

- $\quad \mathrm{N}=$ set of natural number coordinates which identify each cell on the building's façade.

An element's hazard depends on typological characteristics, construction materials and location. However, the presence and rate of the evolution of element degradation must be considered too. The authors refer to the former as intrinsic hazard (PI), and to the latter as extrinsic hazard (PE), which evolves over time if maintenance interventions are not carried out. In this sense, hazard factor (P) can be defined as in Equation (3):

$\mathrm{P}=\left(\mathrm{P}_{\mathrm{I}}\right.$ (construction details, location) $+\mathrm{P}_{\mathrm{E}}($ time, type of anomaly, rate of anomaly evolution $\left.)\right) / 2$

Thus:

$$
\mathrm{P}=\left(\mathrm{P}_{\mathrm{I}}+\mathrm{P}_{\mathrm{E}}\right) / 2
$$

People's vulnerability depends mostly on an element's height and the presence of protective equipment against falling bodies (e.g., safety net, balconies) as in Equation (5):

$$
\mathrm{V}=\mathrm{V} \text { (height,protective equiment) }
$$

Exposure factor depends on accessibility, as it is minimised for non-accessible areas and it is maximised where entrances are placed, so that:

$$
\mathrm{E}=\mathrm{E} \text { (crowding at the building base) }
$$

The building façade risk indicator is the average of the risk values calculated for each cell, and it can be obtained by Equation (7):

$$
\mathrm{Rf}=\sum \mathrm{R}(\mathrm{x}, \mathrm{y}) / \mathrm{n}
$$

where:

- $\mathrm{Rf}=$ building façade risk,

- $\mathrm{n}=$ number of cells.

Therefore, $\mathrm{Rfmin} \leq \mathrm{Rf} \leq \mathrm{Rfmax}$, where minimum and maximum risk values are obtained by considering minimum and maximum values of $\mathrm{PE}$, which is the only factor evolving over time, for each cell (vulnerability and exposure are assumed to not change over medium time period). For a given building's façade, construction details and elements' 
location (intrinsic hazard) are known and they do not depend on the state of decay, as for vulnerability and exposure. For this reason, the risk can be expressed as:

$\mathrm{R}=\mathrm{P} \times \mathrm{V} \times \mathrm{E}=[(\mathrm{PE}+\mathrm{PI}) / 2] \times \mathrm{V} \times \mathrm{E}=[(\mathrm{PE} / 2) \times \mathrm{V} \times \mathrm{E}]+[(\mathrm{PI} / 2) \times \mathrm{V} \times \mathrm{E}]=1 / 2(\mathrm{RE}+\mathrm{RI})$

where RE and RI are, respectively, extrinsic and intrinsic risk indicators. Once the risk map of a certain façade has been defined, assuming that no constructive modification is made nor exposure and vulnerability of people change, the building's owner can evaluate the evolving RE value by means of planned monitoring activities.

The goal of this methodological approach for risk assessment is to verify the acceptability of a façade's risk. Assuming that $\operatorname{ARf}<\operatorname{AR}(x, y)$, where $\operatorname{AR}(x, y)$ stands for the risk acceptance limit of each cell and ARf stands for the risk acceptance limit of the overall façade, two inferences can be made:

- $\mathrm{R}(\mathrm{x}, \mathrm{y})<\mathrm{AR}(\mathrm{x}, \mathrm{y})$,

- $\quad$ Rf $<$ ARf.

Risk acceptance limits are defined according to maintenance management policies. Once ARf has been established, if Rfmin is the façade's risk value at the delivery phase and Rfmax is the theorised maximum risk value which a façade can assume, then it is possible to simulate the risk trend over time as depicted in Figure 1, where it has been assumed that maintenance interventions are made for $\mathrm{Rf}=\mathrm{ARf}$ in order to maintain required performance levels.

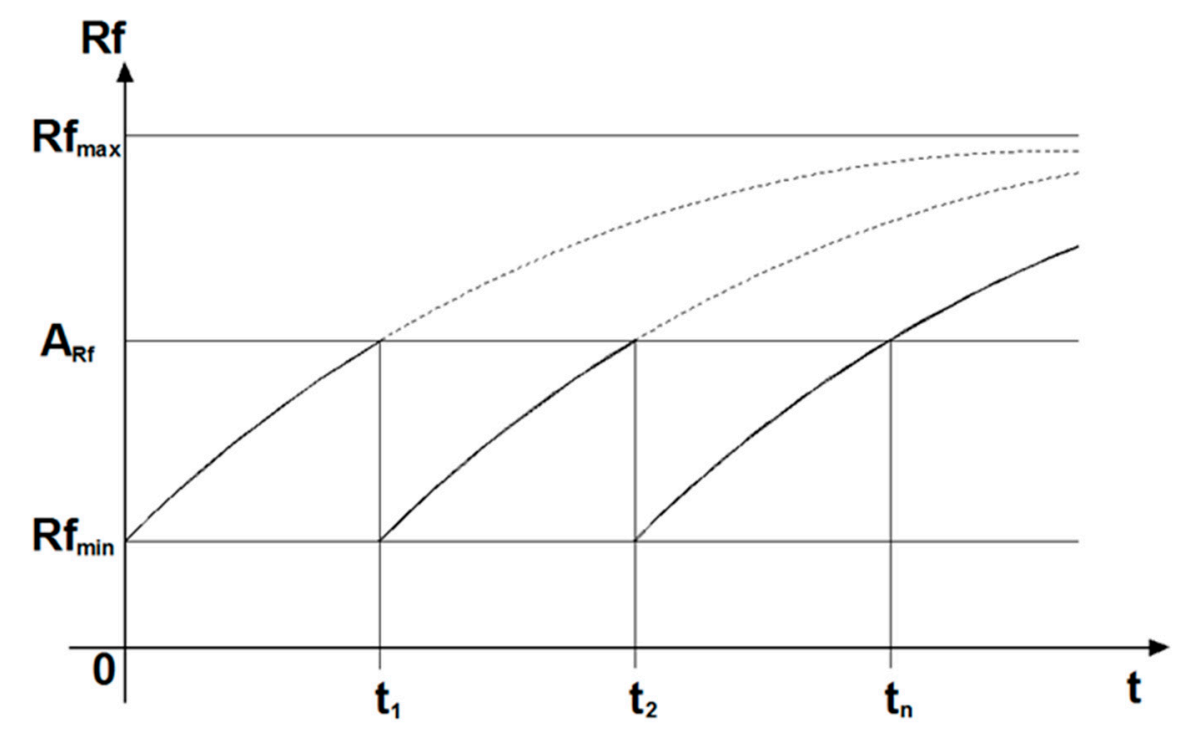

Figure 1. Façade's risk trend over time.

For each façade, three scenarios may occur:

- $\mathrm{R}(\mathrm{x}, \mathrm{y}) \leq \mathrm{AR}(\mathrm{x}, \mathrm{y}) \forall \mathrm{x}, \mathrm{y} \in \mathrm{N}$. Building's façade is safe and the evaluation of the overall risk indicator $\mathrm{Rf}$ can be avoided.

- $\quad R(x, y)>A R(x, y)$ and $\operatorname{Rf} \leq$ ARf. Building's façade is not safe and some cells have an unacceptable risk level, though the overall façade's risk is acceptable. In this scenario, it is necessary to perform maintenance intervention locally. Temporary measures to mitigate the risk are needed to decrease people's vulnerability and/or exposure, such as by means of protective corridors or forbidding access to some entrances.

- $\quad \mathrm{R}(\mathrm{x}, \mathrm{y})>\mathrm{AR}(\mathrm{x}, \mathrm{y})$ and Rf $>$ ARf. Building's façade is not safe and the building's owner/manager needs to intervene with major interventions to improve the overall façade's condition. 


\section{Context of Study: Neapolitan Residential Buildings along Umberto I Avenue}

A specific context of study has been identified for risk quantification and for preliminary analyses of parameter values. To deepen and implement the proposed methodology, the authors focused their research on a specific field of study that is the historic centre of Naples, in Italy. A preliminary analysis has been carried out, reviewing newspaper articles published between 2011 and 2020 on websites reporting collapse events in Naples. Fortytwo cases were collected and analysed, revealing that roof cornices are the most inclined to become hazardous, followed by façades' plasters, frames and balconies (Figure 2).
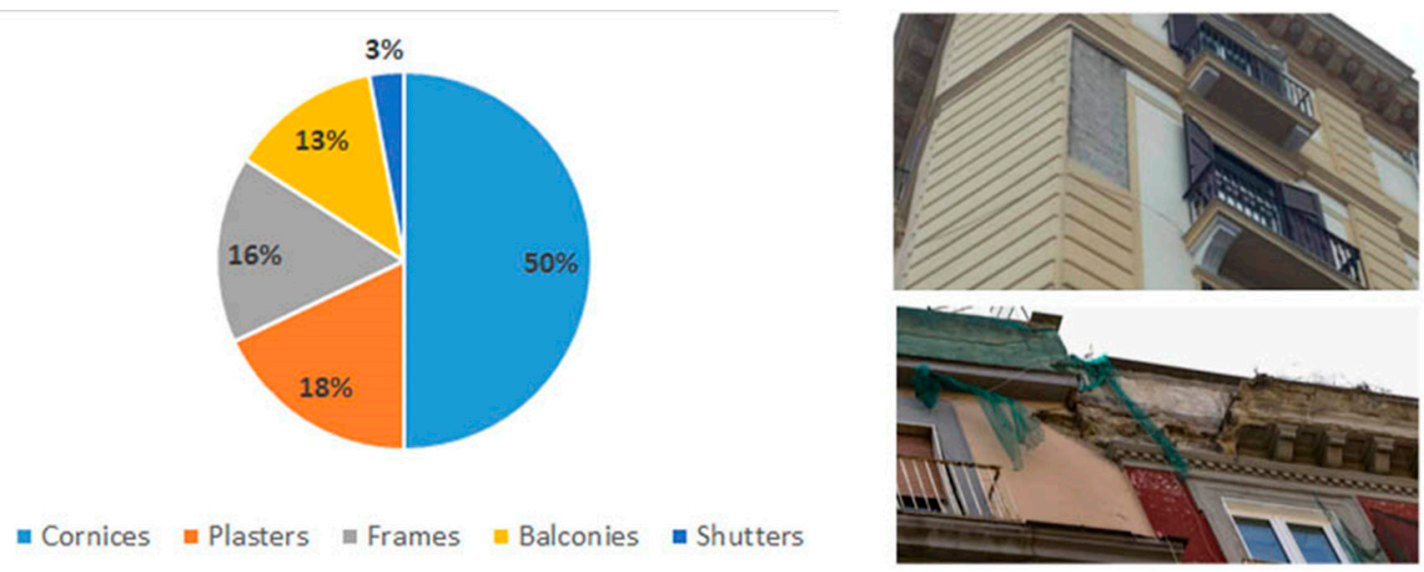

Figure 2. Hazardous elements of historic building façades.

Most of these events (64\%) had no harmful consequences, while 13\% caused damages to objects (i.e., cars and motorcycles), $18 \%$ affected humans (i.e., injuries and concussion) and $5 \%$ led to death. There were no serious injuries for drop heights of less than $10 \mathrm{~m}$ and all reported events regarded elements at least $4 \mathrm{~m}$ above the ground.

The review of collapse events reported in Naples led the authors to the definition of the vulnerability matrix. A value, which can vary between 1 and 10 , has been assigned to each possible protective item, considering that the most dangerous is the element with the highest corresponding value, as in Table 1, where $\mathrm{H}$ stands for the drop height.

Table 1. Vulnerability values.

\begin{tabular}{cccc}
\hline Protective Elements & \multicolumn{3}{c}{ Vulnerability } \\
\hline None & $\mathrm{H} \leq 4 \mathrm{~m}$ & $4 \mathrm{~m}<\mathrm{H} \leq 9 \mathrm{~m}$ & $\mathrm{H}>9 \mathrm{~m}$ \\
Jutting balconies $>40 \mathrm{~cm}$ & 2 & 6 & 10 \\
Most prominent balconies & 1 & 4 & 6 \\
Protective & 1 & 2 & 1 \\
corridors/scaffolding & 1 & 1 & 2 \\
\hline
\end{tabular}

Exposure factor values can vary between 1 and 10 and they depend on the crowding at the ground of the building's façades. Its value is maximum for entries on crowded streets, while it is minimum for unfrequented streets where there are no entries, as in Table 2. To assess the crowding at the ground of the building, the authors referred to the Italian guidelines for crosswalk design, which suggest headcount and vehicular count at the rush hour. 
Table 2. Exposure values.

\begin{tabular}{cccc}
\hline Crowding at the Ground & Pedestrian Flow & Vehicular Flow & E \\
\hline None & $0 \mathrm{p} / \mathrm{h}$ & $0 \mathrm{v} / \mathrm{h}$ & 1 \\
Low & $<50 \mathrm{p} / \mathrm{h}$ & $<100 \mathrm{v} / \mathrm{h}$ & 3 \\
Moderate & $<50-100 \mathrm{p} / \mathrm{h}$ & $<100-200 \mathrm{v} / \mathrm{h}$ & 5 \\
High & $<100-300 \mathrm{p} / \mathrm{h}$ & $200-600 \mathrm{v} / \mathrm{h}$ & 8 \\
Very high & $>300 \mathrm{p} / \mathrm{h}$ & $>600 \mathrm{v} / \mathrm{h}$ & 10 \\
\hline
\end{tabular}

In order to determine elements' intrinsic and extrinsic hazards, the authors identified a specific set of buildings placed in the historic centre of Naples as a reference. Masonry residential buildings, along Umberto I avenue, have been examined in order to define a homogeneous database to study. These façades have all been restructured at the beginning of the 20th century and offer similar construction techniques and materials. They were rebuilt by the same company, which provided standardised specifications about interventions to make.

A total of 16 buildings and 37 façades have been analysed, with a total of 26,000 square meters. Each building's façade has been analysed in terms of surfaces occupied by forming elements and encountered anomalies as defined by UNI 11182:2006. Façades have been considered planar, so that the amount of surface due to balconies and other ledges is not taken into account. Frequent anomalies include discoloration, cracks, exfoliation, deposits, missing parts and gaps.

A consistent part (38\%) of the analysed façades has safety nets as protective measures against falling bodies from balconies and cornices (Figure 3); this finding outlines the relevance of the event in Naples.
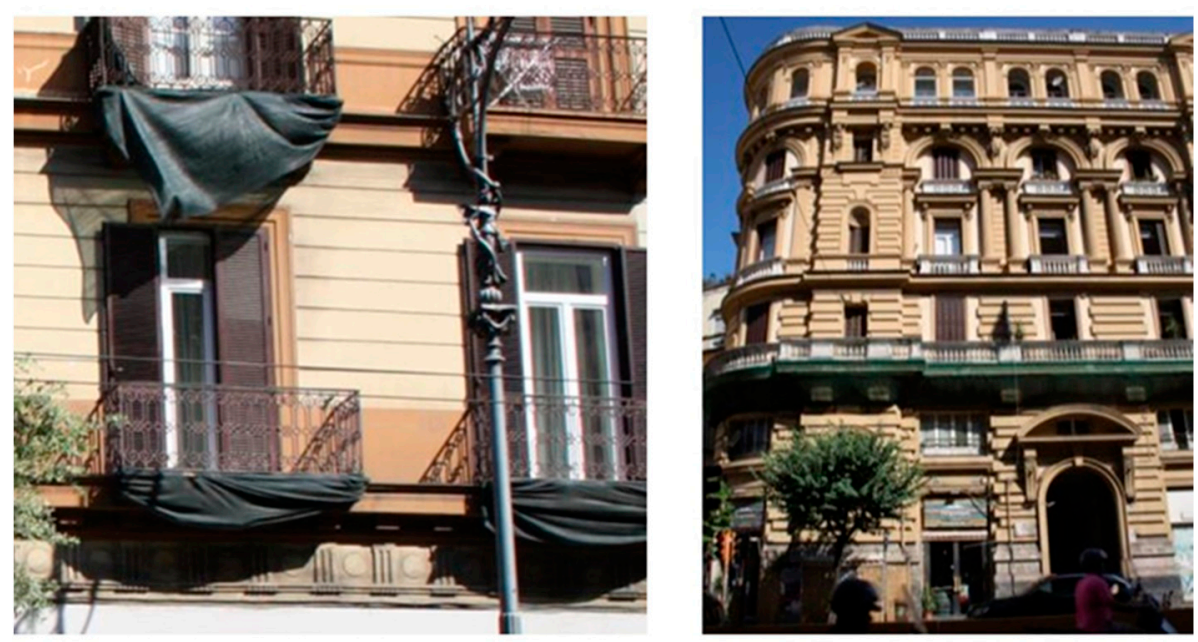

Figure 3. Examples of protective measures (balcony at the first floor and containment nets) along the examined avenue.

Elements' intrinsic hazard due to construction materials and technologies has been defined by evaluating the percentage of surfaces affected by gaps in relation to the total surface of each element, as in Figure 4. 


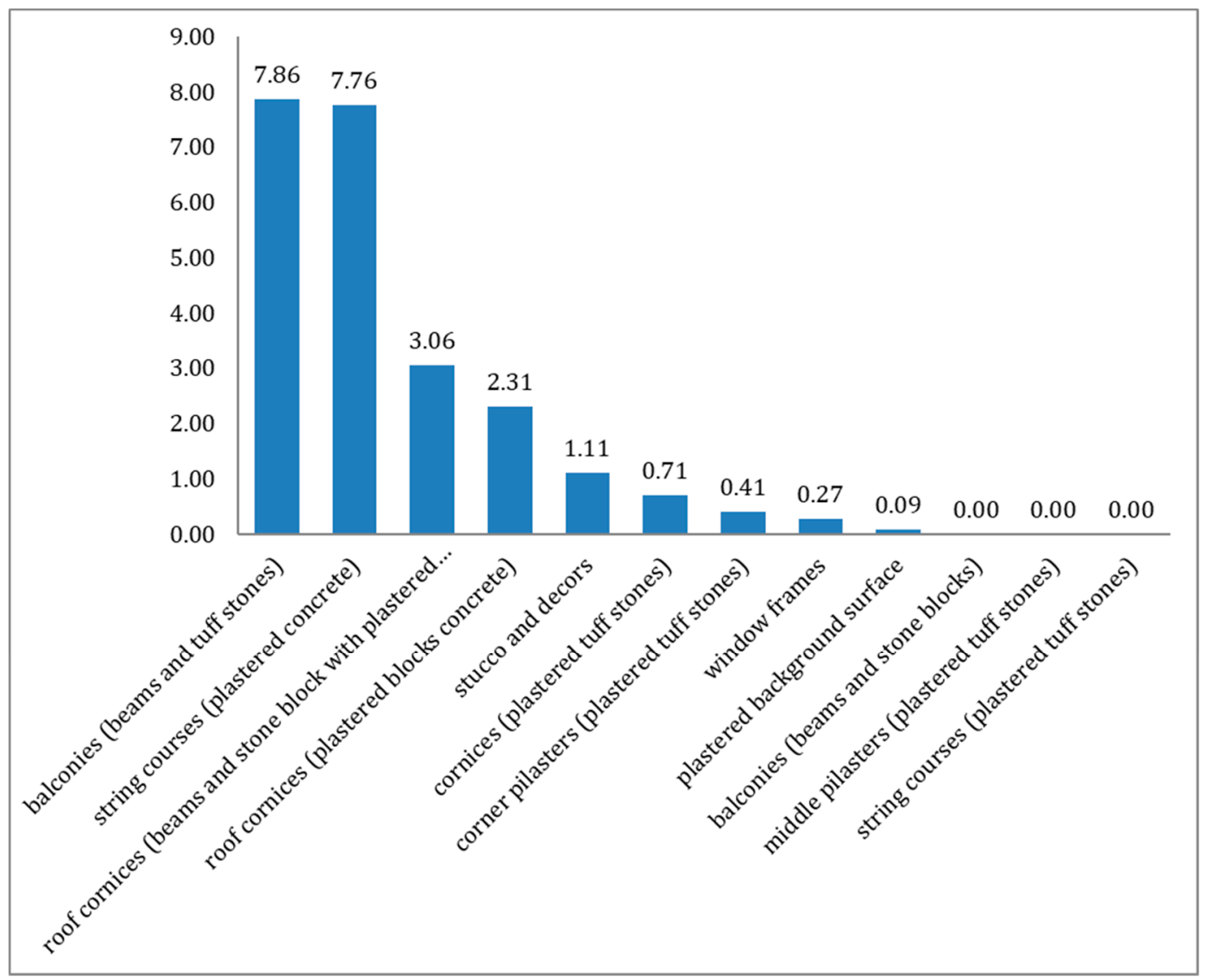

Figure 4. Percentage of element surfaces presenting gaps.

Balconies and roof cornices resulted in being the most affected by gaps. Furthermore, falling items regarded elements' corners. It can be deduced that balconies and roof cornices' intrinsic hazards are the highest, and the amount of projecting surface does not influence elements' hazard (Figure 5).
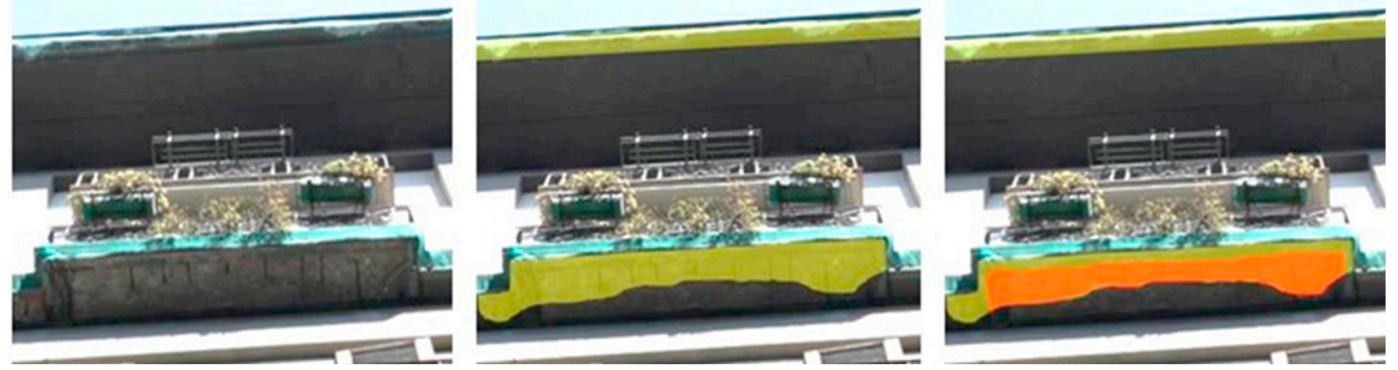

Figure 5. Corner's surfaces (in yellow) are affected by gaps, the remaining parts (in red) can be considered less dangerous as their falls will probably be stopped by lower balconies.

Roof cornices can be considered more dangerous than balconies as they are the most projecting elements of a façade, thus there are no protective items (i.e., balconies) against possible falling bodies. Over $80 \%$ of surfaces were affected by diffuse anomalies (i.e., several gaps), that is to say, elements affected by localized gaps are inclined to become worse and to provoke harmful events over time.

Among the examined Neapolitan buildings, the authors listed and catalogued façade elements according to their typological and construction characteristics as well as their 
location. Intrinsic hazard values, which can vary between 1 and 10, have been assigned to each element. A very hazardous element, such as the roof cornice placed at the corner, covered by plaster and made of steel beams and bricks, has the highest intrinsic hazard value (10), while a balcony made of steel beams and stone blocks has the lowest hazard value (1).

In order to define extrinsic hazard values, the authors listed those identified in the panel of examined Neapolitan buildings, considering the list of stone deterioration patterns defined by UNI 11182:2006 as a reference. To each kind of anomaly, an extrinsic hazard value has been assigned, taking into account the rate of evolution of such an anomaly. Those values can vary from 1 to 10 , from the least to the most dangerous kind of anomaly. For shutters and fixtures, the following scale has been used, referring to the state of conservation: good (1); average (5); poor (10). The presence of missing parts of a certain element in one cell influences the extrinsic hazard (PE) of other contiguous cells by increasing $(+2)$ the PE of those cells which include that element affected by gaps.

Tables 3 and 4 report, respectively, an extract of intrinsic hazard values (PI) matrix and an extract of extrinsic hazard values (PE) matrix.

Table 3. Extract of intrinsic hazard values (PI) matrix.

\begin{tabular}{lc}
\hline \multicolumn{1}{c}{ Type of Element } & PI \\
\hline Balcony (steel beams and stone blocks) & 1 \\
Plastered background surface & 2 \\
Shutters & 3 \\
String courses (plastered tuff) & 3 \\
Plastered pilaster & 3 \\
String courses of plastered tuff, placed at the corner & 4 \\
Stucco and decors on tuff support & 4 \\
Plastered pilaster at the corner & 5 \\
Roof cornice of plastered tuff with corbels & 5 \\
Roof cornice of plastered tuff with corbels, placed at the corner & 6 \\
\hline
\end{tabular}

Table 4. Extract of extrinsic hazard values (PE) matrix.

\begin{tabular}{cccc}
\hline Type of Anomaly & \multicolumn{3}{c}{ PE } \\
\hline & Stable & Evolving & Fast evolving \\
Discolouring & 1 & 1 & 1 \\
Deposit & 2 & 3 & 4 \\
Alveolization & 5 & 6 & 7 \\
Missing part (gaps) & 8 & 9 & 10 \\
\hline
\end{tabular}

\section{Results}

The validation and the proof of concept of the methodological approach presented in this paper are provided by an application on a building falling within the specific field of study introduced before.

As mentioned, Umberto I avenue offers a set of similar façades built mostly at the beginning of the 20th century. In fact, in the late 19th century, the historic centre of Naples suffered a cholera epidemic, which led to a restoration plan known as the "disembowelment plan" (they demolished old buildings in order to enlarge the streets and they rebuilt buildings' façades) to improve urban health and hygiene. A new construction company was organized specifically for this purpose, which concluded the renovation interventions by 1920. The review of historical tender specifications reported in De Sivo et al. [30] was essential for the purpose of this paper, as it led to a deep knowledge of construction materials and techniques used during the reconstruction process. Buildings' façades are composed of tuff masonry, from 5 metres to 90 centimetres in width, decorated with plaster and stucco elements. Plasters were installed following specific rules, moving from a rough layer (made of sand and lime) to a finishing layer (which added marble powder). 
For cornices and frames, concrete was added to the mortar before the stucco finishing surface. Roof cornices, of great interest in this paper, were built upon stone blocks (tuff stones or lapillus mortar) covered by a concrete mortar and finished with stucco. In cases of projections greater than $50 \mathrm{~cm}$, a reinforced structure was necessary to sustain them (Figure 6). Balconies could vary from $50 \mathrm{~cm}$ to $110 \mathrm{~cm}$ and they were made of steel beams, with a spacing of $80 \mathrm{~cm}$, and tuff stones or drilled bricks. Other cornices, frames and pilasters were obtained by plastered masonry.
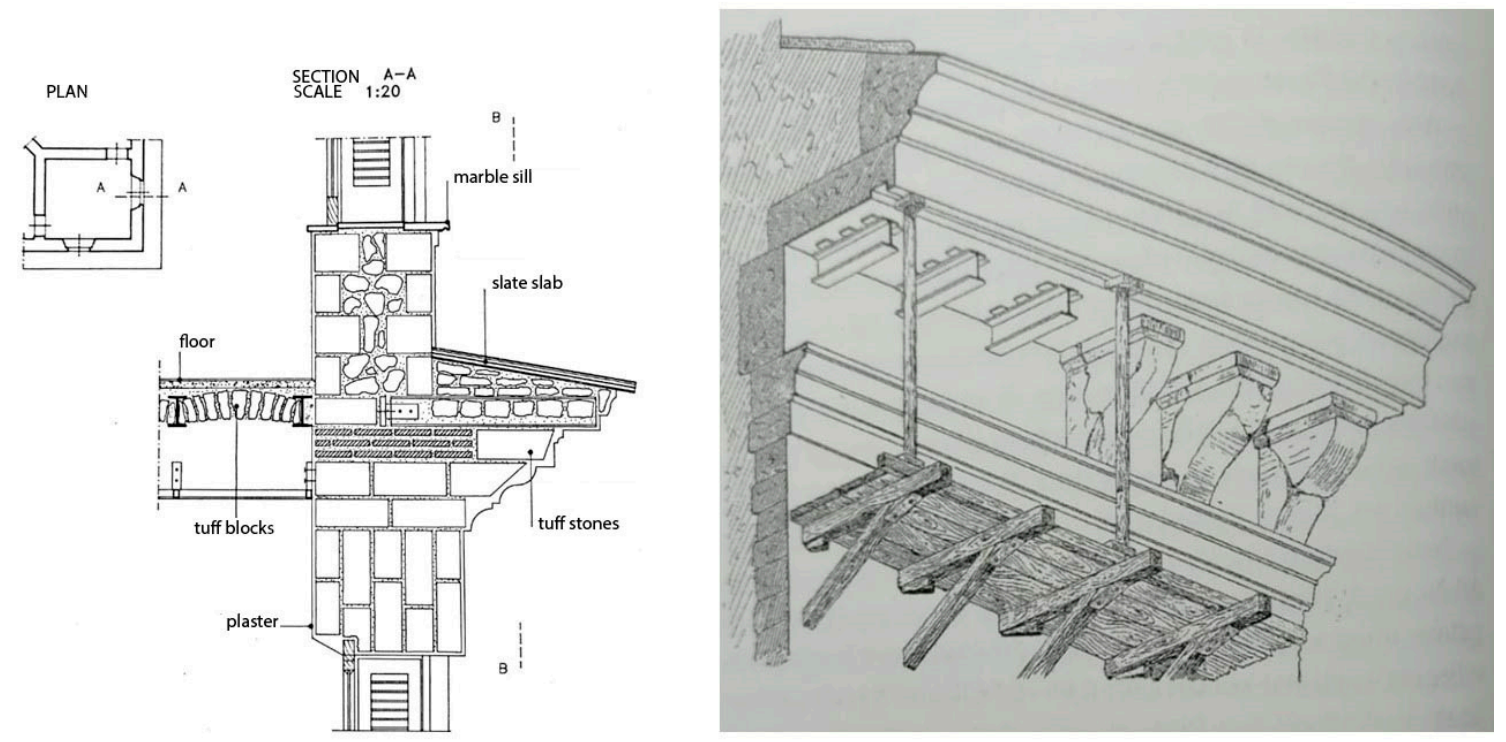

Figure 6. Examples of construction materials and elements of roof cornices (based on [11], pp. 230,306).

The case study developed in this paper regards a residential building along Umberto I avenue. Its façade is characterised by plastered stuff masonry and balconies with steel beams and stone blocks. The overall state of conservation of the examined façade is good (Figure 7). Intrinsic hazard values (PI values reported in Table 3) have been assigned to each façade's elements, as specified below:

- $\quad$ Shutters: 3

- $\quad$ Balconies (steel beams and stone blocks): 1

- $\quad$ String courses of plastered tuff: 3

- $\quad$ String courses of plastered tuff, placed at the corner: 4

- $\quad$ Plastered pilaster: 3

- $\quad$ Plastered pilaster at the corner: 5

- $\quad$ Roof cornice of plastered tuff with corbels: 5

- $\quad$ Roof cornice of plastered tuff with corbels, placed at the corner: 6.

Considering the extrinsic hazard values of Table 4, the authors assigned to each façade's element a PE value. Comparative analysis of the rate of the evolution of degradation phenomena was not available, so identified anomalies were considered fast evolving as a security advantage. Vulnerability values have been assigned considering those reported in Table 1. Finally, exposure values have been assigned according to Table 2, considering that the analysed façade faces one of most crowded Neapolitan streets, where many commercial activities are placed. The resulting maps are depicted in Figure 8. 


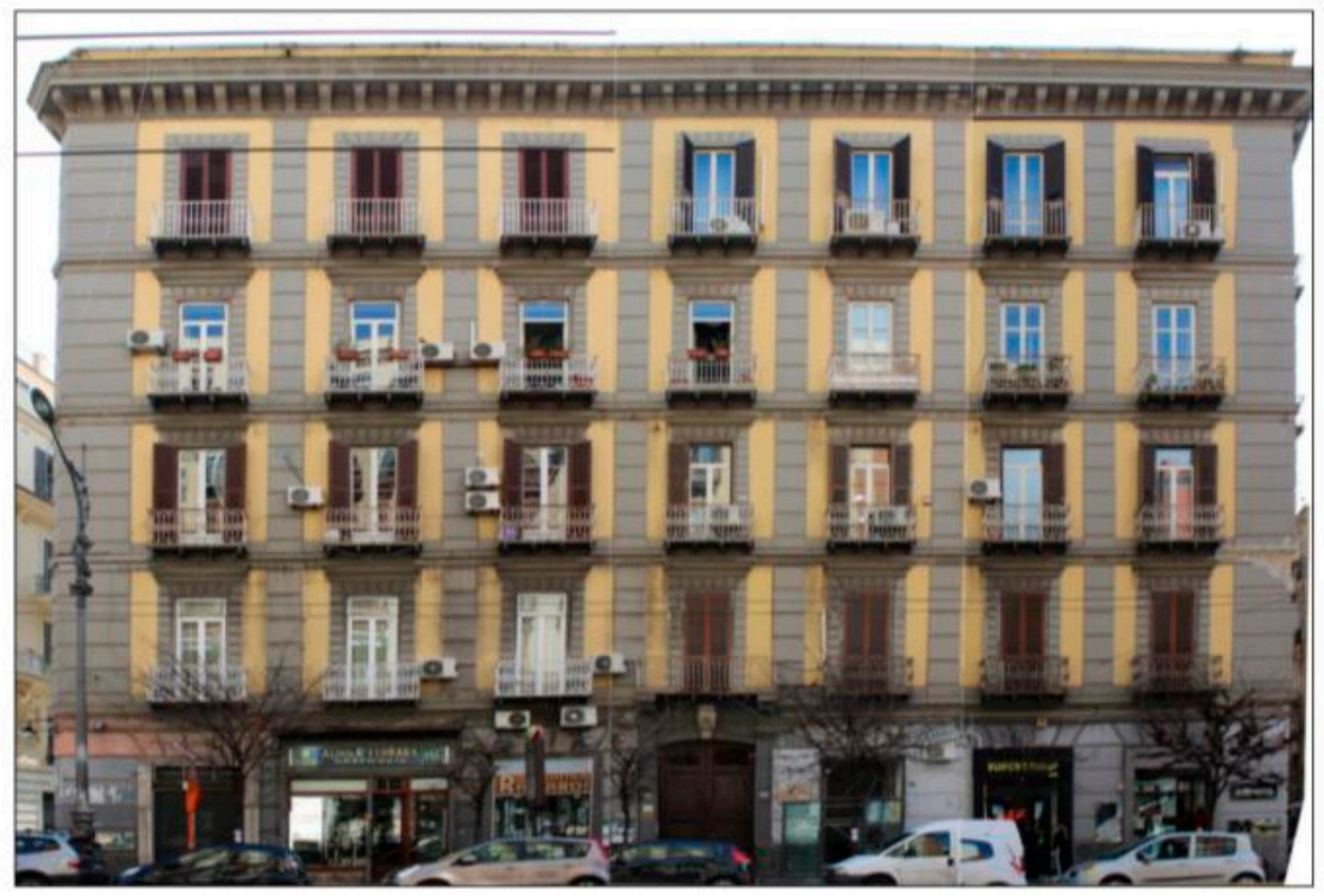

Figure 7. Analysed façade.
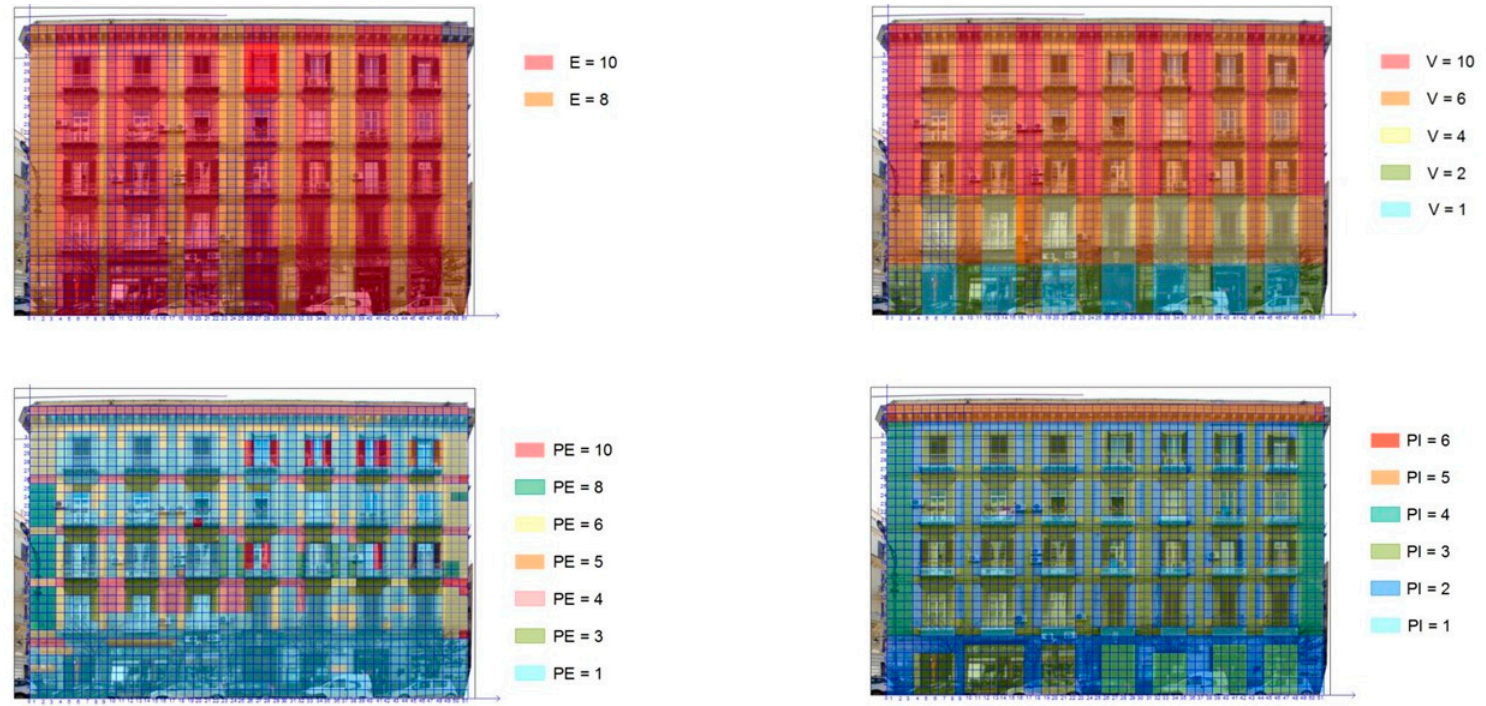

$$
\begin{aligned}
P E & =10 \\
P E & =8 \\
P E & =6 \\
P E & =5 \\
P E & =4 \\
P E & =3 \\
P E & =1
\end{aligned}
$$
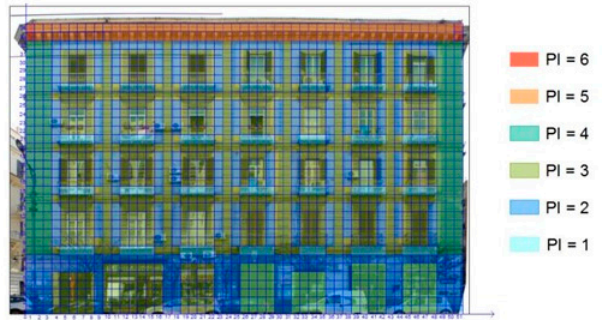

Figure 8. Exposure, Vulnerability, Extrinsic hazard and Intrinsic hazard maps.

The arising risk map is reported in Figure 9. The overall risk indicator $(\mathrm{Rf}=159)$ falls within the third quadrant of a hypothetical risk dashboard (Figure 10), considering that the minimum risk for the analysed façade is $\mathrm{Rfmin}=105$ and the maximum is $\mathrm{Rfmax}=339$. Indeed, for a given façade, it is possible to determine its minimum and maximum risk value corresponding to the best-case scenario (e.g., at the delivery phase) and the worst case scenario (e.g., assuming highest values of hazard, vulnerability and exposure can be applied). The resulting risk range can be divided, as a first approximation, into four parts equally. To each interval, a qualitative judgement can be associated (low, medium, high, very high risk). In this way, it is possible to perform qualitative assessment of the same 
building at different moments (which can help with monitoring the trend of a façade's risk over time) or to compare several buildings' façades at once or different moments (this can provide policies about where to intervene more urgently).

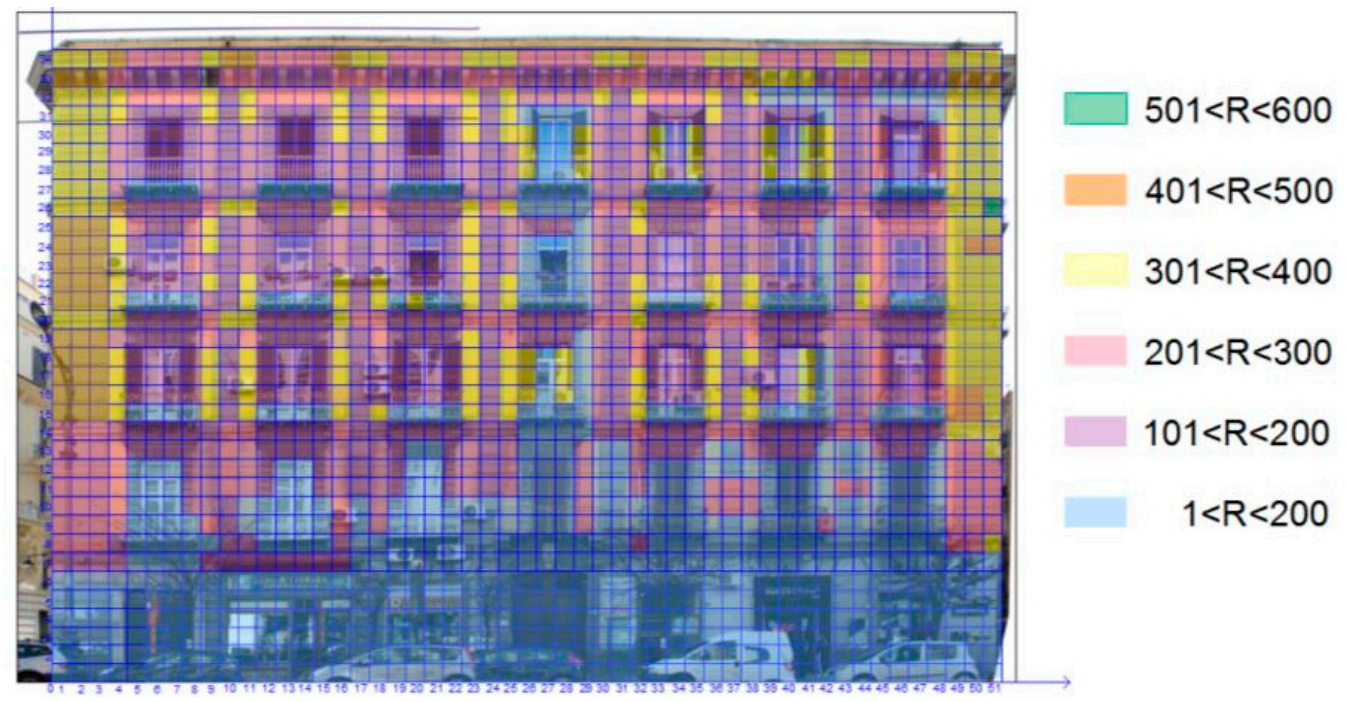

Figure 9. Façade's risk map.

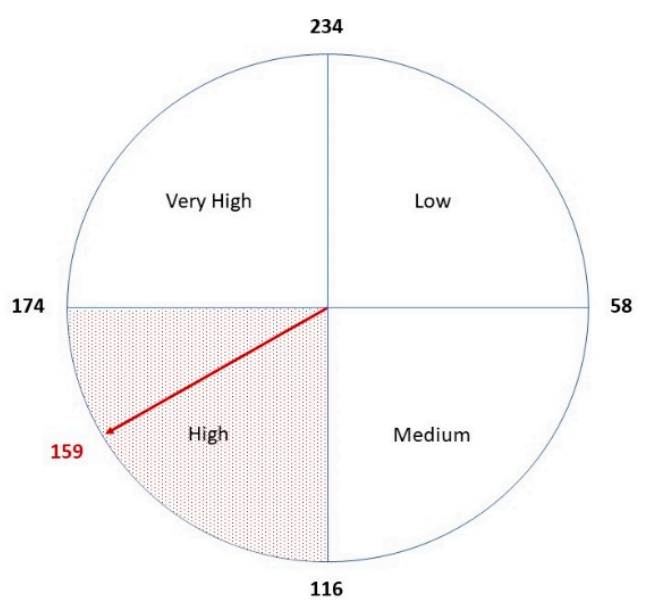

Figure 10. Risk dashboard.

\section{Discussion}

Preventive maintenance actions, especially in historic cities, can reduce the economic impact of urgent interventions on deteriorated buildings while increasing their service life and reducing damages to cultural heritage. For these purposes, several studies provided tools and methods to assess building condition and vulnerability through the evaluation of the state of conservation or decay. The proposed methodological approach goes beyond those aimed at preserving cultural heritage by extending the field of interest to people's safety against falling bodies from historic buildings' façades. The results presented in this paper show that:

- Even though operational and environmental conditions affect the conservation of architectural heritage, they are the main factors to be considered when assessing the risk to humans related to those buildings too. Protective measures against falling bodies from balconies and cornices are common in Naples, indeed, to testify the relevance of the risk connected with those harmful events (Figure 3). 
- $\quad$ Starting from a well-known risk definition, which comprises hazard, vulnerability and exposure, the authors interpreted these parameters in an original way and proposed new definitions focused on reducing risks to humans. Building façade risk maps (Figures 8 and 9) developed by the authors support different analysis, focused on exposure, vulnerability, intrinsic/extrinsic hazards and on the resulting risk.

- $\quad$ The main items for risk assessments (i.e., hazard, vulnerability, exposure) must be evaluated by analysing the context (i.e., environmental factors) and the intrinsic characteristics (i.e., materials, construction details, location) of each building. It is possible to identify homogenous contexts and sets of buildings to speed up the evaluation process on an asset portfolio, developing matrixes of risk factor values (Tables 1-4). Moreover, when the risk map of a certain façade has been implemented for the first time, the building's owner and/or manager can assess the evolving risk by means of inspections and planned monitoring activities regarding the state of decay, assuming that others risk factors did not change.

- Quantitative measurements can help with monitoring the trend of a façade's risk over time (Figure 1), and risk dashboards (Figure 10) support benchmarking analysis within an asset portfolio to prioritise maintenance actions. According to the risk map, the building's owner can evaluate maintenance tasks to undertake both in terms of space planning (where to intervene) and programming (where to intervene first).

- The risk acceptability has not been determined yet. To date, the achieved results concern risk variables and procedures for performance assessment, which are the first steps for further investigation on risk acceptability and quantitative measurements. If acceptance threshold values, for specific categories of buildings, have been defined, then appropriate actions for given values can be prescribed. It is necessary to analyse three scenarios for each façade, corresponding to different risk conditions according to the overall façade's state and risk values of each cell belonging to the façade's map.

\section{Conclusions}

Current research on the evaluation of the material degradation of historic buildings is mainly focused on the loss of cultural heritage rather than people's safety assessment. This paper argues for a methodological approach for risk assessment due to falling bodies from historic buildings' façades, which is a big challenge in historic centres such as the Neapolitan one. It identifies parameters, such as hazard, vulnerability, and exposure, to describe building façade risk from a new perspective, which is people's safety against falling bodies from historic façades. A novel performance indicator is defined as a combination of these parameters to quantify and assess the risk. A specific field of application has been examined in order to deepen and implement the methodology. The overall historic Neapolitan centre has been used as a reference to define vulnerability and exposure matrixes, while a specific avenue has been analysed in detail to specify intrinsic and extrinsic hazard values. This avenue offers a set of residential buildings, restructured during the same years by a single construction company, characterised by similar construction techniques and details. Finally, a case study provides the validation of the proposed approach. The presented approach has valuable practical implications on the maintenance management policies of historic buildings. The exposed results allow qualitative performance assessment, which can help building owners and managers to monitor the risk trend over time, developing a façade's risk map and prioritizing maintenance tasks accordingly. Parameters and procedures for performance assessment are prior steps for determining risk threshold values and for identifying needed interventions. If risk threshold values have been established, the relevance of maintenance intervention (minor or major) might be deduced by applying such an approach.

This paper is part of a study regarding the definition of criteria for choosing proper maintenance interventions aimed at ensuring public safety. Thus, future improvements will regard the definition of an acceptability threshold value for the risk indicator of a façade in order to improve the feasibility of the method. The research is currently limited to a specific 
sector of the Neapolitan historic centre. Further efforts are needed to define elements' hazard matrixes for other contexts and different types of buildings. The risk assessment process can also be automatized by means of artificial intelligence which, moving from the façade's operational conditions survey, leads to the evaluation of the risk indicator for each cell and as a consequence for the overall façade.

Author Contributions: Writing—original draft preparation, G.R.; writing—review and editing, R.M. and M.N.; supervision, M.N. All authors have read and agreed to the published version of the manuscript.

Funding: This research received no external funding.

Conflicts of Interest: The authors declare no conflict of interest.

\section{References}

1. Cecchi, R.; Gasparoli, P. La Manutenzione Programmata dei Beni Culturali Edificati; Alinea srl: Florence, Italy, 2011; pp. 9-38. ISBN 8860556686.

2. Cecchi, R. Roma Archaeologia. Interventi per la Tutela e la Fruizione del Patrimonio Archeologico; Electa: Milan, Italy, 2011; Volume I, ISBN 88-370-8738-1.

3. Ortiz, R.; Macias-Bernal, J.M.; Ortiz, P. Vulnerability and buildings service life applied to preventive conservation in cultural heritage. Int. J. Disaster Resil. Built Environ. 2018, 9, 31-47. [CrossRef]

4. Ortiz, R.; Ortiz, P. Vulnerability index: A new approach for preventive conservation of monuments, International. J. Archit. Herit. 2016, 10, 1078-1100. [CrossRef]

5. Daniotti, B.; Spagnolo, S.L. La banca dati sulla durabilità dei componenti edilizi. In Sostenibilità e Innovazione in Edilizia; Aracne: Ariccia, Italy, 2008. [CrossRef]

6. $\quad$ Perret, J. Guide de la Maintenance des Batiments; Le Moniteur: Paris, France, 1995.

7. Société de contrôles techniques Socotec. Guide Socotec de la Maintenance et de la Réhabilitation; Le Moniteur: Paris, France, 2001.

8. Re Cecconi, F.; De Angelis, E. Guasti in Edilizia—Ammaloramento Dell'edificio, Suggerimenti di Ripristino e di Prevenzione—Banca Dati dei Guasti; Maggioli editore: Rimini, Italy, 2008.

9. de Brito, J.; Pereira, C.; Silvestre, J.D.; Flores-Colen, I. Expert Knowledge-Based Inspection System; Springer: Cham, Switzerland, 2020. [CrossRef]

10. Dekker, R.; Nicolai, R.P.; Lodewijk, C.M.; Kallenberg, L.C.M. Maintenance and Markov Decision Models, in Encyclopedia of Statistics in Quality and Reliability; John Wiley \& Sons, Ltd.: Hoboken, NJ, USA, 2008. [CrossRef]

11. Mazzuchi, T.A.; Noortwijk, J.M.; Kallen, M. Maintenance Optimization. In Encyclopedia of Statistics in Quality and Reliability; John Wiley \& Sons, Ltd.: Hoboken, NJ, USA, 2008. [CrossRef]

12. van Winden, C.; Dekker, R. Rationalisation of building maintenance through Markov decision models. In Operations Research Proceedings 1993 (GOR (Gesellschaft für Operations Research e.V.); Springer: Berlin/Heidelberg, Germany, 1994; Volume 1993. [CrossRef]

13. Paulo, P.; Branco, F.; de Brito, J.; Silva, A. The use of genetic algorithms for maintenance plan optimization. J. Clean. Prod. 2016, 121, 84-98. [CrossRef]

14. Alwan, Z.; Gledson, B.J. Towards green building performance evaluation using asset information modelling. Built Environ. Proj. Asset Manag. 2015, 5, 290-303. [CrossRef]

15. de Brito, J.; Silva, A. Life Cycle Prediction and Maintenance of Buildings. Buildings 2020, 10, 112. [CrossRef]

16. Lind, H.; Muyingo, H. Building maintenance strategies: Planning under uncertainty. Prop. Manag. 2012, 30, 14-28. [CrossRef]

17. Ferreira, C.; Silva, A.; de Brito, J.; Dias, I.S.; Flores-Colen, I. The impact of imperfect maintenance actions on the degradation of buildings' envelope components. J. Build. Eng. 2021, 33, 101571. [CrossRef]

18. Lee, H.; Scott, D. Overview of maintenance strategy, acceptable maintenance standard and resources from a building maintenance operation perspective. J. Build. Apprais. 2009, 4, 269-278. [CrossRef]

19. Faqih, F.; Zayed, T. A comparative review of building component rating systems. J. Build. Eng. 2021, 33, 101588. [CrossRef]

20. Abbott, G.R.; McDuling, J.J.; Parsons, S.A.; Schoeman, J.C. Building condition assessment: A performance evaluation tool towards sustainable asset management. In CIB World Building Congress 2007: Construction for Development: Book of Abstracts; Theo C. Haupt: Cape Town, South Africa, 2007; pp. 649-662.

21. Pedro, J.B.; Paiva, J.V.; Vilhena, A. Portuguese method for building condition assessment. Struct. Surv. 2008, $26,322-335$.

22. Straub, A. Dutch standard for condition assessment of buildings. Struct. Surv. 2009, 27, 23-35. [CrossRef]

23. Eweda, A. An Integrated Condition Assessment Model for Educational Buildings Using BIM; Concordia University: Montreal, QC, Canada, 2012.

24. Housing Health and Safety Rating System (HHSRS). Available online: https://www.housinglin.org.uk/Topics/type/TheHousing-Health-and-Safety-Rating-System-HHSRS/ (accessed on 2 February 2021).

25. U.S. Department of Education. Facilities Information Management. A Guide for State and Local Education Agencies; National Center for Education Statistics (NCES): Washington, DC, USA, 2003.

26. Ho, D.C.; Chau, K.W.; King-Chung Cheung, A.; Yau, Y.; Wong, S.K.; Leung, H.F.; Siu-Yu Lau, S.; Wong, W.S. A survey of the health and safety conditions of apartment buildings in Hong Kong. Build. Environ. 2008, 43, 764-775. [CrossRef] [PubMed] 
27. Dejaco, M.C.; Re Cecconi, F.; Maltese, S. Key performance indicators for building condition assessment. J. Build. Eng. 2017, 9, 17-28. [CrossRef]

28. Salim, N.A.A.; Zahari, N.F. Developing integrated building indicator system (IBIS) (a method of formulating the building condition rating). Proc. Eng. 2011, 20, 256-261. [CrossRef]

29. Re Cecconi, F.; Dejaco, M.C.; Maltese, S. Efficiency indexes for building condition assessment. Int. J. Hous. Sci. 2014, 38, 271-279.

30. Cecchi, R.; Gasparoli, P. Manuale del Recupero Delle Antiche Tecniche Costruttive Napoletane; CUEN: Napoli, Italy, 1996; ISBN 88-86701-13-6. 